\title{
Pooled Mean Group Approach to Test the Determinants of Financial Integration: Evidence From OECD and G20 Countries
}

\author{
Ahliman Abbasov ${ }^{1}$ \\ ${ }^{1}$ Azerbaijan State University of Economics, Azerbaijan \\ Correspondence: Ahliman Abbasov, Azerbaijan State University of Economics, Azerbaijan.
}

Received: September 30, 2019

Accepted: November 15, 2019 Online Published: December 15, 2019

doi:10.5430/rwe.v10n3p366

URL: https://doi.org/10.5430/rwe.v10n3p366

\begin{abstract}
This study investigates the role of financial liberalization, trade integration, economic growth and global financial crisis on financial integration level of selected OECD and G20 countries during the period of 2000-2016. PMG technique has been implemented to estimate the ARDL model. Regression results suggest a statistically significant long run co-integration relationship between financial integration and independent variables. Analysis also concludes that there are both long run and short run positive impact of trade integration level on financial integration level. The study also concludes that the global financial crisis has had a negative influence on global financial integration both in the short run and long run. But according to the regression results the impact of financial liberalization on the actual financial integration level of the countries only appears in the long run. Results also indicate that positive impact of economic growth on financial globalization level appears only in the long run.
\end{abstract}

Keywords: financial globalization, financial integration, financial liberalization, open economies, open economy macroeconomics

\section{JEL Codes: F3, F4}

\section{Introduction}

Global financial integration or financial globalization is not a new phenomenon and has gone through different development stages. Financial globalization had rapid development pace during the gold standard from 1880 to 1914. But as the world war erupted in 1914 financial globalization began to lose its momentum. The level of international financial integration decreased further after the onset of Great Depression and the Second World War. This interwar period saw significant drop of the level of cross-border capital movement and rise of capital restrictions. As the Second World War ended and a new global financial system was agreed financial globalization entered its gradual recovery period and gained significant pace since the 1970s. Technological advances, financial deregulation policies and geopolitical changes had caused even more integrated global financial system by the end of $20^{\text {th }}$ century. During the early years of $21^{\text {st }}$ century developing countries also joined to financial liberalization process and the scale of cross border flows steadily increased year by year. But the degree of financial integration among countries have always been different. Advanced countries had played a much bigger role than the emerging countries on the pre-crisis global financial integration process. Especially the banking system of advanced countries had a central role on the rise of financial globalization. But the dynamics of international financial integration has changed a lot since the 2008-2009 global crisis. Nearly all forms of capital flows faced a decline, but international banking was affected more severely than others. The reduction in cross-border capital flows was not homogenous across countries and regions (Milesi-Ferretti and Tille, 2010). Collapse in capital flows has been more temporary for emerging markets than for advanced countries. That is why emerging countries' role on the progress of financial globalization has expanded since 2008-2009 global crisis.

Several studies point out trade integration, financial policies, economic performance, geography, international agreements, technological progress, financial infrastructure as potential factors that cause countries to have differentiated level of financial integration (Lane and Milesi-Ferretti,2003; Xuan Vinh Vo, 2007; Ivan Arribas,Francisco Perez and Emili Tortosa-Ausina, 2009). This study aims to investigate the role of trade integration, financial liberalization, economic growth and global financial crisis on financial integration level of selected OECD and G20 countries during the period of 2000-2016. The structure of the rest of the paper is as follows. Section 2 reviews the empirical literature on the international financial integration. Section 3 provides the empirical model and 
data. Empirical methodology of the analysis is discussed in section 4. Results of the estimation are presented and explained in section 5. Finally, Section 6 concludes.

\section{Litarature Review}

Lane and Milesi-Ferretti (2003) study the impact of different variables (GDP per capita, trade openness, external liberalisation, financial depth, stock market capitalisation, privatisation revenues etc.) on foreign assets and liabilities. The study concludes that international trade and stock market capitalisation are the two most significant factors affecting external balance sheets. Kevin James Daly and Xuan Vinh Vo (2007) provide the empirical investigation of the drivers of international financial integration. They include financial liberalization, economic development, education, country risk index, financial development depth of financial markets, openness of international trade and tax policy as the determinants of financial integration. They found that financial liberalization, trade openness, domestic credit and economic growth are factors that may explain the degree of financial integration. Ivan Arribas, Francisco Perez and Emili Tortosa-Ausina (2009) analyzed the role of networks and geographic position on the international integration of banking systems in 18 advanced economies from 1999 to 2005 . They implement a technique based on both network analysis and the concept of geographic neutrality. Results of this study indicate the significant role of geographic distance and trade integration on the degree of banking globalization.

M. Ayhan Kose et al (2009) indicate that policies promoting financial sector development, institutional quality and trade openness help developing countries derive the benefits of globalization. Their study claims that sound macroeconomic policies are an important prerequisite for ensuring that financial integration is beneficial. The analysis also suggests that the relationship between financial integration and economic policies is complex. Philip Lane (2012) examines the relationship between financial globalization and crisis. He found financial globalisation provided a buffer against the crisis for some countries. But in some countries financial integration intensified the negative consequences of the crisis. He claims that the global crisis has proved that financial globlization increases the costs of policy and regulatory failures. Arjana Brezigar-Masten, Fabrizio Coricelli, Igor Masten (2010) provide an empirical analysis of the role of financial development and financial integration in the growth dynamics of transition countries. They focus on the role of financial integration in determining the impact of financial development on growth, distinguishing "normal times" from periods of financial crises. Results of the study confirms that the financial development and financial integration have significant positive effect on growth. Study also concludes that a higher degree of financial openness tends to reduce the contractionary effect of financial crises and high reliance on international capital flows by transition countries does not necessarily stimulate financial instability. Zuzana Kučerová (2013) empirically assess the relationship between financial and trade integration in the EU member countries over the period 1993-2012. The analysis concludes that there is a linear relationship between financial and trade integration in the pre-crisis period (1993-2007), especially in the EU10 countries (compared to the EU16 countries). The study also indicates that the financial crisis undermined the relationship between financial and trade integration. Abbasi, Brauning, Fecht, Jose-Luis Pyedro, (2017) study how financial crisis affect international financial integration in case of Euro Area Interbank Crises. They found that crisis shocks reduce the supply of cross-border liquidity, thereby reducing the level of international financial integration.

This study will contribute the existing literature by examining the 2008-2009 crisis as one of the factors affecting the development of global financial integration level in case of the G20 and OECD countries. Most of the previous studies either do not provide the statistical effect of the global financial crisis on financial globalization or focus on regional financial integration in their analysis. Similar researches by Lane and Milessi-Ferretti (2003), Daly and Vo (2007) analyzed the factors affecting financial crisis in the pre-crisis period. Lane (2012) examined the impact of financial integration on financial crisis, but not vice versa. Recent works by Kucerava (2013) and Abbasi, Brauning, Fecht and Jose-Luis Pyedro (2017) focused on financial integration only among EU and Eurozone cuontries. But this work includes 41 countries which play important role in global economic and financial system. Another contribution of my research to the existing literature is distinguishing the short run and long run impacts of the determinants of financial integration by implementing autoregressive distributed lag model (ARDL).

\section{Model and Data}

The following regression model has been constructed to test the determinants of financial integration in OECD and G20 countries from 2000 to 2016:

$$
\text { FinInt }_{i t}=\alpha_{o i}+\alpha_{1 i} \text { FinLib }_{i t}+\alpha_{2 i} \text { TrInt }_{i t}+\alpha_{3 i} \text { Growth }_{i t}+\alpha_{4 i} \text { Crisis }_{i t}+u_{i t}, \quad i=1, \ldots, N ; t=1, \ldots, T
$$

Where "FinInt" is the degree of financial integration of a country, FinLib indicates the level of financial liberalization, "TrInt" is the level of trade integration of a country, "Growth" inticates the GDP growth level, "Crisis" 
is a dummy variable for the 2008-2009 global financial crisis and $\mathrm{u}_{\mathrm{t}}$ is the error term of regression. The subscripts $i$ and $t$ denote country and time, respectively.

In this study, panel data for 41 countries and period of 2000-2016 has been used to examine the relationship between financial integration and financial liberalization, trade integration, economic growth, financial crisis. Table 1 indicates the list of countries that have been included to the analysis. The data for financial integration, trade integration and financial liberalization have been obtained from KOF Globalization Index 2018. De facto financial globalization index, de facto trade globalization index, de jure financial globalization index are used for financial integration, trade integration and financial liberalization, respectively. The KOF Globalization index originally was introduced by Dreher (2005), but the Gygli et al. (2019) developed them and provided a more comprehensive subset of indexes. Niklas Potrafke (2014) summarizes more than hundred empirical studies that have used these indexes. The data for GDP growth has been taken from World Bank database.

Table 1. Selected 41 countries

\begin{tabular}{lllllll}
\hline Argentina & Australia & Austria & Belgium & Brazil & Canada & Switzerland \\
Chile & China & Czechia & Germany & Denmark & Italy & Ireland \\
Iceland & France & Luxembourg & Norway & Portugal & Spain & Greece \\
Turkey & USA & UK & Japan & Finland & New Zealand & Holland \\
Estonia & Hungary & Poland & Slovak Rep. & South Korea & Latvia & Lithuania \\
Russia & Mexico & Indonesia & India & South Afrika & Saudi Arabia & \\
\hline
\end{tabular}

\section{Methodology}

The panel autoregressive distributed lag (ARDL) model has been used in order to capture both the long run and short run relationship between dependent and explanatory variables. According to Pesaran and Shin (1999) panel ARDL can be employed to estimate the models with variables that are $\mathrm{I}(0), \mathrm{I}(1)$, or both $\mathrm{I}(0)$ and $\mathrm{I}(1)$. Even in case of the possible endogeneity problem the coefficients of ARDL estimation are considered consistent, as the model includes lags of both dependent and independent variables. The Panel ARDL model can be introduced as follows:

$$
Y_{i t}=\sum_{j=1}^{p i} \lambda_{i j} Y_{i, t-j}+\underset{j=1}{\sum} \delta_{i j} X_{i, t-j}+\mu_{\mathrm{i}}+\varepsilon_{i t}
$$

where $Y_{i t}$ is the scalar dependent variable (financial integration), $\lambda_{i j}$ are scalar coefficients of lagged dependent variables, $X_{i t}$ is the ( $\left.k x \quad l\right)$ vector of regressors (financial liberalization, trade integration, growth and crisis dummy) for group $i, \delta_{i j}$ are $(k x 1)$ are coefficent vectors, $\mu_{\mathrm{i}}$ indicates fixed effects (Pesaran et al.,1997). Pesaran et al. (1997) also presented the re-parameterized form of equation (1):

$$
\Delta Y_{i t}=\phi Y_{i, t-1}+\beta_{i} X_{i, t}+\sum_{\mathrm{j}=1}^{\mathrm{p}-1} \lambda_{i j}^{*} \Delta Y_{i, t-j}+\sum_{\mathrm{j}=1}^{\mathrm{q}-1} \delta_{i j}^{*} \Delta X_{i, t-j}+\mu_{\mathrm{i}}+\varepsilon_{i t}
$$

Pooled mean group technique introduced by Pesaran et al. (1999) has been chosen to estimate the panel ARDL model. Pooled mean group (PMG) estimator of dynamic panels is very useful for large number of time observations and large number of groups. In PMG estimation the long-run coefficients are not allowed to vary across countries, but it allows the short-run coefficients and error variances to differ. Long run coefficients and the group specific error-correction coefficients are computed through maximum likelihood estimation.

\section{Results and Discussion}

According to the AIC lag selection procedure ARDL $(2,2,2,2)$ model has been chosen as an optimal model. Table 3 illustrates the results of the PMG estimation of ARDL $(2,2,2,2)$ model. Estimation of the model has provided statistically significant negative error correction term, which proves long run cointegration relationship between dependent and independent variables. Long run coefficents indicate that in the long run financial liberalization, trade integration and economic growth have had statistically significant positive impact on the level of financial integration of the countries. Estimation output suggests that 1 unit increase of the trade globalization index 
accompanies with 0.110546 unit increase of de facto financial globalization index in the long run. 1 unit increase of the financial liberalization has caused 0.477684 unit rise of the financial integration index. And 1 unit increase of economic growth has contributed 0.246299 increase of the financial integration index. Results also reflect that in the long run the 2008-2009 financial crisis has had statistically significant negative impact on financial integration. According to the regression results financial crisis has caused index of financial globalization to be 10.32128 unit lower in the long run.

\begin{tabular}{lllll}
\hline \multicolumn{5}{c}{ Long run equation } \\
\hline Variable & Coefficient & Std.error & t-stat. & Prob. \\
\hline FinReg & 0.477684 & 0.056496 & 8.455164 & $0.0000^{* * *}$ \\
\hline TrFlow & 0.110546 & 0.035096 & 3.149825 & $0.0018^{* * *}$ \\
\hline Growth & 0.246299 & 0.099945 & 2.464353 & $0.0144^{* *}$ \\
\hline Crisis & -10.32128 & 0.741956 & -13.91090 & $0.0000^{* * *}$ \\
\hline \multicolumn{5}{c}{ Short run equation } \\
\hline Cointeq01 & 0.041471 & -4.831510 & $0.0000^{* * *}$ \\
\hline $\mathrm{D}$ (FinFlow(-1)) & -0.200369 & 0.074631 & 0.169217 & 0.8658 \\
\hline $\mathrm{D}$ (Finreg) & 0.012629 & 0.039022 & -0.232634 & 0.8162 \\
\hline $\mathrm{D}$ (Finreg(-1)) & -0.002078 & 0.049148 & -1.674604 & $0.0953^{*}$ \\
\hline $\mathrm{D}($ Trflow) & -0.082304 & 0.124737 & 2.100864 & $0.0367^{* *}$ \\
\hline $\mathrm{D}($ Trflow(-1)) & 0.262055 & 0.125386 & 2.496274 & $0.0132^{* *}$ \\
\hline $\mathrm{D}($ Growth) & 0.312998 & 0.068368 & -1.169701 & 0.2433 \\
\hline $\mathrm{D}($ Growth $(-1))$ & -0.206112 & 0.102758 & 1.309103 & 0.1917 \\
\hline $\mathrm{D}($ Crisis $)$ & 0.134521 & 0.480026 & -3.809614 & $0.0002^{* * *}$ \\
\hline $\mathrm{D}$ (Crisis(-1)) & -1.828714 & 1.201207 & 2.928670 & $0.0037^{* * *}$ \\
\hline $\mathrm{C}$ & 3.517940 & 0.927879 & 7.032695 & $0.0000^{* *}$ \\
\hline $\mathrm{N}$ & 6.525488 & &
\end{tabular}

Note: $* * *, * *, *$ are $1 \%, 5 \%, 10 \%$ significance level, respectively.

Estimation of short run equation concludes short run positive impact of both current and lagged value of trade integration variable on financial integration level. According to short run coefficients financial crisis variable without lag has statistically significant negative impact on financial integration. Regression output reflects that in the short run financial crisis has caused financial globalization index to be 1.828714 unit lower. But the lagged value of crisis variable has had positive impact on the financial integration level in the short run. Results show that lagged value of the financial crisis variable has contributed financial integration index to be 3.517940 unit higher. As the cross border financial flows started to increase immediately after the crisis, this regression result seems consistent. Both current and lagged value of GDP growth variable do not show statistically significant impact on dependent variable in the short run. The short run coefficient of financial liberalization variable also lacks statistical significance. Lagged value of financial liberalization is significant under 10 per cent significance level, but the sign of the coefficent is not acceptable from the theoretical point of view.

\section{Conclusion}

The pace of the development of financial globalization has been different since the beginning of $21^{\text {st }}$ century. Rapid pace of global financial integration has started to slow down since the onset of global financial crisis. Understanding the role of different factors on ups and downs of financial globalization is key to predict the future of global financial system. This study provides the empirical analysis the impact of financial liberalization, trade integration, economic growth, financial crisis on financial integration. The study have huge significance to understand the potential effect of current trade tensions, slower global economic growth and threat of next financial crisis on the development of global financial integration.

PMG technique has been implemented to estimate the ARDL model with 4 explanatory variables- financial liberalization, trade integration, GDP growth and global financial crisis. Regression results suggest a statistically significant long run cointegration relationship between financial integration, financial liberalization, trade integration, 
economic growth and financial crisis. Analysis also concludes that there are both long run and short run positive impact of trade integration level on financial integration level. As country's trade globalization measure increases, financial globalization measure also increases both in the short run and long run. The study also concludes that the global financial crisis has had a negative influence on global financial integration both in the short run and long run. Panel ARDL estimation reflects that the scale of negative long run impact of GFC on financial globalization has been much stronger that its short run impact. But according to the regression results the impact of financial liberalization on the actual financial integration level of the countries only appears in the long run. Results also indicate that in the long run the economic growth level of the selected countries has had statistically significant positive impact on their financial globalization level. But the analysis does not find any significant short run impact of economic growth on the financial integration level.

\section{References}

Arjana Brezigar-Masten, Fabrizio Coricelli, \& Igor Masten. (2010). Financial integration and financial development in transition economies: what happens during financial crises?. Documents de travail du Centre d'Economie de la Sorbonne 10021, Université Panthéon-Sorbonne (Paris 1), Centre d'Economie de la Sorbonne.

Axel Dreher. (2006). Does Globalization Affect Growth? Evidence from a new Index of Globalization. Applied Economics, 38(10), 1091-1110.

Ayhan Kose, Eswar Prasad, Kenneth Rogoff, \& Shang-Jin Wei. (2006). Financial Globalization: A Reappraisal. International Monetary Fund WP/06/189.

Ayhan Kose, Eswar Prasad, Kenneth Rogoff, \& Shang-Jin Wei. (2009). Financial Globalization and Economic Policies, February, IZA DP No. 4037.

Gian-Maria Milesi-Ferretti, \& Cédric Tille. (2010). The Great Retrenchment: International Capital Flows During the Global Financial Crisis. IHEID Working Papers 18-2010, Economics Section, The Graduate Institute of International Studies, revised 15 Sep 2010.

Nasha Ananchotikul, Shi Piao, \& Edda Zoli. (2015). Drivers of Financial Integration -Implications for Asia. International Monetary Fund WP/15/160.

Niklas Potrafke. (2015). The Evidence on Globalization. The World Economy, 38(3), 509-552.

Pesaran, M. H., \& Shin, Y. (1999). An Autoregressive Distributed Lag Modelling Approach to Cointegration Analysis. In Strom, S. (Ed.), Chapter 11 in Econometrics and Economic Theory in the 20th Century the Ragnar Frisch Centennial Symposium (pp. 371-413). Cambridge University Press, Cambridge.

Pesaran, M. H., Shin, Y., \& Smith, R. P. (1997). Pooled estimation of long-run relationships in dynamic heterogeneous panels, University of Cambridge, Department of Applied Economics.

Pesaran, M. H., Shin, Y., \& Smith, R.P. (1999). Pooled mean group estimation of dynamic heterogeneous panels. Journal of the American Statistical Association, 94(446), 621-634.

Philip R Lane. (2012). Financial Globalisation and the Crisis. BIS Working Paper No. 397.

Philip R. Lane, \& Gian Maria Milesi-Ferretti, (2008). The Drivers of Financial Globalization. IIIS Discussion Paper No. 238.

Philip R. Lane, \& Gian Maria Milesi-Ferretti. (2003). International Financial Integration, IMF Staff Papers Vol. 50, Special Issue.

Philip R. Lane, \& Gian Maria Milesi-Ferretti. (2017). International Financial Integration in the Aftermath of the Global Financial Crisis. International Monetary Fund WP/17/115.

Puriya Abbassi, Falk Bräuning, Falko Fecht, \& Jose-Luis Peydro. (2017). International Financial Integration, Crises, and Monetary Policy: Evidence from the Euro Area Interbank Crises. FRB of Boston Working Paper No. 17-6.

Savina Gygli, Florian Haelg, Niklas Potrafke, \& Jan-Egbert Sturm. (2019). The KOF Globalisation Index - Revisited. Review of International Organizations.

Xuan Vinh Vo, \& Kevin James Daly. (2007). The determinants of international financial integration. Global Finance Journal, 18(2), 228-250.

Zuzana Kučerová. (2013). Financial and trade integration in the EU countries. Acta Universitatis Agriculturae et Silviculturae Mendelianae Brunensis, 61(4), 981-993. 